\title{
Salinity induced physiological and biochemical changes in chickpea (Cicer arietinum $\mathbf{L}$.) genotypes
}

\author{
Pavneetpal Kaur, Jagmeet Kaur ${ }^{1 *}$, Satvir Kaur ${ }^{2}$, Sarvjeet Singh ${ }^{1}$ and Inderjit Singh ${ }^{1}$ \\ Department of Botany, Punjab Agricultural University, Ludhiana, INDIA \\ ${ }^{1}$ Department of Plant Breeding and Genetics ${ }^{*}$, Punjab Agricultural University, Ludhiana, INDIA \\ ${ }^{2}$ Department of Biochemistry, Punjab Agricultural University, Ludhiana, INDIA \\ *Corresponding author. E-mail : jagskaur@gmail.com
}

Received: June 03, 2014; Revised received: August 21, 2014; Accepted: November 01, 2014

\begin{abstract}
Plant growth and development are adversely affected by salinity- a major environmental stress that limits agricultural production. Chickpea (Cicer arietinum L.) is sensitive to salinity that affects its yield and there is need to identify the tolerant genotypes. The present study was conducted to evaluate the effect of salinity on chickpea genotypes with specific physiological and biochemical attributes contributing to their adaptability to salinity stress. Seven chickpea genotypes both desi (ICC8950, ICCV10, ICC15868, GL26054) and kabuli (BG1053, L550, L552) were evaluated for salinity tolerance. Maximum decrease in relative leaf water content and chlorophyll content was observed with ICC15868 and GL26054 among the desi and L552 from the kabuli genotypes. The photosynthetic pigments, activity of nitrate reductase and relative leaf water content was also reduced in response to salt application with effect being more pronounced in ICC15868, GL26054 and L552 as compared to ICC8950, ICCV10, BG1053 and L550. Lipid peroxidation increases with the increase in $\mathrm{NaCl}$ concentration, maximum increment was observed in genotypes ICC15868, GL26054 and L552. Accumulation of proline in response to environmental stresses seems to be widespread among plants. Higher protein fractions were observed with tolerant genotypes in contrast to sensitive genotypes. Salt imposed stress finally caused a higher decline in number of filled pods. On the basis of physiological and biochemical parameters genotypes ICC8950 and ICCV10 from the desi genotypes and BG1053 and L550 from kabuli were identified as the tolerant while ICC15868, GL26054 as the sensitive ones and L552 as the moderately tolerant genotypes. These genotypes could be used as a source of tolerance in breeding programme to develop salt tolerant genotypes.
\end{abstract}

Keywords: Biochemical, Chickpea, Physiological, Salinity

\section{INTRODUCTION}

Plants are exposed to wide range of environmental stresses like high temperature, cold, drought, salinity, alkalinity, UV and pathogen infection. Abiotic stress is the primary cause of crop loss worldwide by more than $50 \%$ (Rasool et al. 2013). Salinity is one of the major abiotic stresses causing severe impact on crop production worldwide as out of the world's 1.5 billion hectares of cultivable land, 77 million hectares $(5 \%)$ do not favor good yields due to high salt content and $20 \%$ of the irrigated agricultural land is adversely affected by salinity. Salt-affected soils are increasing steadily in all the continents, in particular in arid and semiarid areas which cover more than $7 \%$ of the total land surface on earth (Selvakumar et al., 2014). More than $800 \mathrm{M}$ ha of arable lands worldwide are affected by salinity, and this area is expanding and is posing as an ever threat to food production (Munns and Tester, 2008).

Soil salinity is becoming more problematic due to the increase in irrigation around the world. Salinity not only decreases the agricultural production of most crops, but also, as a result of its effect on soil physicochemical properties, adversely affects the associated ecological balance of the area. The harmful impacts of salinity include low agricultural production, low economic returns due to high cost of cultivation, reclamation, management, soil erosion due to high dispersibility of soil, ecological imbalance due to halophytes and marine life forms from fresh water to brackish water, poor human health due to toxic effects of accumulated elements (Hu and Schmidhalter, 2002). Resistance to salt stress does not rely on a single trait but, on the contrary, it has a very complex nature as it depends upon various morphological and biochemical traits. The availability of water to the growing tissue becomes a limiting factor under saline conditions even in the presence of moisture in the soil resulting in what is termed as "Physiological Drought". Water uptake by plants hence, attains importance under saline conditions. The reduction in photosynthesis, respiration and protein synthesis due to salinity reduced crop yield (Meloni et al., 2003). The primary effect of salinity stress is hyperionic and hyperosmotic stress and in severe cases cause oxidative stress in plants (Ahmad et al., 2012). Oxidative stress is responsible for the 
generation of reactive oxygen species (ROS) which are deleterious to plants (Azooz et al., 2011, Ahmad et al., 2012). ROS are highly reactive and cause damage to biomolecules such as lipids, proteins and nucleic acids (Tuteja et al., 2009). Proline is considered as the only osmolyte which has been shown to scavenge singlet oxygen and free radicals including hydroxyl ions. It also serves as redox potential regulator and protects macromolecules such as proteins, DNA and reduces enzyme denaturation caused by heat, $\mathrm{NaCl}$ and other stresses (Kumar et al., 2010). Lipid molecules, in general and unsaturated lipids, in particular are sensitive to oxidation by ROS. Consequently, the presence of elevated levels of thiobarbituric acid reactive species (TBARS), a product of lipid peroxidation, is generally an indicator of free radical damage to cell membranes causing severe oxidative stress (Metwally et al., 2005). Nitrate reductase (NR) is the first and key enzyme of nitrate assimilation and is involved in nitrogen metabolism, play important role in amino acid biosynthesis, and regulates the protein synthesis (Harris et al., 2000). Proteins may be synthesized de novo in response to salt stress or may be present constitutively at low concentration and increase when plants are exposed to salt stress (Pareek et al., 1997). Therefore, it is important to study nitrate reductase activity and protein expression in genotypes. Chickpea is one of the important legume crops conventionally cultivated in marginal areas and saline soils (Rao et al., 2002). It is the world's third largest food legume crop and is a highly valued commodity being an important source of proteins for human consumption in several developing countries (Hameed et al., 2012; Zaccardelli et al., 2013). Chickpea is particularly sensitive to salinity and the annual salt induced yield losses of 8 to $10 \%$ globally occur in chickpea (Flowers et al., 2010). In an earliar study it was observed that saline treatment $(40 \mathrm{mM} \mathrm{NaCl})$ significantly decreased the seed yield in chickpea genotypes and genotypic variation for salinity tolerance exists in chickpea (Turner et al., 2013). In India, Punjab is severely affected by salinity problem. About 85,000 ha of agricultural land is affected by water logging and salinity (Anonymous, 2009). This problem is again aggravated as ground water in many parts of Punjab contains high concentration of dissolved salts with electrical conductivity between 2 to $7 \mathrm{dS} \mathrm{m}^{-1}$ (Shakya and Singh, 2010). Depleting water table due to rice wheat rotation is further enhancing to salinity problem and chickpea is most affected due to shifting it to marginal lands. Chickpea being sensitive to salinity needs considerable enhancement of salinity tolerance to be grown on natural saline soil. Therefore an understanding of the mechanisms involved in salt tolerance of the chickpea plant is crucial to select salt tolerant genotypes or to engineer salt sensitive genotypes with genetic traits to include salt tolerance. Keeping all the factors in mind the present investigation was formulated to study the effect of salt stress in chickpea genotypes at different crop development stages (vegetative, flower initiation and pod initiation) and on seed protein expression. The tolerant chickpea (Cicer arietinum L.) genotypes will be identified on the basis of physiological and biochemical indices.

\section{MATERIALS AND METHODS}

Seven genotypes of chickpea $C$. arietinum both kabuli (BG1053, L550, L552) and desi (ICC8950, ICCV10, ICC15868, GL26054) were raised in pots with/without holes in six replications. These genotypes having contrasting behaviour for salinity tolerance were selected out of 20 genotypes evaluated earlier by us for seedling growth and germination behaviour under salt stress $(30 \mathrm{mM} \mathrm{NaCl})$ in pots. Plants were grown under saline and non saline conditions in $27 \mathrm{~cm}$ diameter plastic pots containing $10 \mathrm{~kg}$ of soil fertilized with fertilizers as per recommended package of practices for chickpea. Pots with holes were used for control conditions and the pots without holes were used for saline treatments. The experiment was carried out in open-air facility equipped with a rainout shelter. The saline treatment at 20 and $30 \mathrm{mM} \mathrm{NaCl}$ was applied in split dose: at the time of sowing and 15 days after sowing (DAS) in a sufficient volume to wet the soil to field capacity. Non saline treated controls were irrigated with tap water. In all the treatments seven seeds were sown in each pot and later thinned to 4 plants per pot at 30 DAS. The physiological (chlorophyll content, relative leaf water content, lipid peroxidation) and biochemical parameters (nitrate reductase, proline content) were estimated in leaves of control and salt treated plants at vegetative (65DAS), flower initiation (90DAS) and at pod initiation stages (110DAS). Characterization of proteins and protein profiling was carried out from dry seeds at maturity.

Estimation of chlorophyll: The chlorophyll content from fresh leaves (100 mg) was extracted with dimethyl sulphoxide (DMSO) (Hiscox and Israelstam, 1979). The tubes were kept in water bath at $65^{\circ} \mathrm{C}$ for $30 \mathrm{~min}$. $1 \mathrm{ml}$ of aliquot was mixed with $2 \mathrm{ml}$ DMSO and vortexed. Absorbance was determined photometrically at 645 and $663 \mathrm{~nm}$ using DMSO as blank.

Estimation of relative leaf water content (RLWC): Fresh leaf $(100 \mathrm{mg})$ sample was submerged in $10 \mathrm{ml}$ distilled water till saturation and kept overnight. Surface water of the leaves was blotted off without putting any pressure and then were weighed to obtain saturated weight. After drying the leaves at $70^{\circ} \mathrm{C}$ for $72 \mathrm{~h}$ their dry weight was obtained. From these data RLWC was calculated by Barr and Weatherley method (1962).

RLWC $=($ Fresh weight-Dry weight $) \times 100 /$ Saturated weight-Dry weight

Estimation of lipid peroxidation : Lipid peroxidation was determined by measuring the amount of 
malondialdehyde (MDA) produced by the thiobarbituric acid (TBA) reaction (Heath and Packer, 1968). Fresh leaves (100 mg) were ground in $1 \%$ TCA $(10 \mathrm{ml} / \mathrm{g}$ fresh weight) with a mortar and pestle and then was centrifuged at $10,000 \mathrm{rpm}$ for $5 \mathrm{~min} .1 .0 \mathrm{ml}$ of supernatant was taken in a separate test tube, to which $4.0 \mathrm{ml}$ of $0.5 \%$ TBA was added. The mixture was heated at $95^{\circ} \mathrm{C}$ for $30 \mathrm{~min}$ and after cooling in an ice bath it was centrifuged at 5,000 rpm for $5 \mathrm{~min}$ for clarification. Absorbance was recorded at $532 \mathrm{~nm}$ and corrected for unspecific turbidity by subtracting the value at $600 \mathrm{~nm}$. The concentration of MDA was calculated using an extinction coefficient of 155 $\mathrm{mM}^{-1} \mathrm{~cm}^{-1}$.

Extraction and estimation of nitrate reductase: Nitrate reductase was estimated from the leaves by using the method of Jaworski (1971). Leaves were cut into small pieces (approximately $1 \mathrm{~mm}$ size) and $0.2 \mathrm{~g}$ sample was suspended in $5 \mathrm{ml}$ of $0.1 \mathrm{M} \mathrm{KNO}_{3}$ (in $0.1 \mathrm{M}$ phosphate buffer $\mathrm{pH} 7.5$ ) solution in $25 \mathrm{ml}$ test tube. The tubes were thereafter, incubated in the dark in a water bath for 30 minutes. At the end of incubation period, the tubes were placed in the boiling water bath for $10 \mathrm{~min}$ to stop the enzymatic reaction. After boiling, the tubes were cooled and filtered to remove small pieces of leaflets. The clear supernatant thus obtained was used for estimating nitrate reductase. 0.5 $\mathrm{ml}$ of sample extract was took out and to it $1 \mathrm{ml}$ of $1 \%$ sulphanilamide solution was added to it. After $5 \mathrm{~min}, 1$ $\mathrm{ml}$ of $0.02 \% \mathrm{~N}$-(1-naphthyl) ethylene diamine dihydrochloride was added and pink colored solution obtained after 30 minutes was measured at $540 \mathrm{~nm}$ against reagent blank.

Estimation of proline content : The leaf samples $(100 \mathrm{mg})$ after extraction with methanol:chloroform:water (12:5:1) were centrifuged for 10 minutes and the supernatant was collected. The contents were recentrifuged after adding $4 \mathrm{ml}$ of methanol: chloroform : water. Supernatant were pooled and final volume was made upto $10 \mathrm{ml}$ with same solvent. To this $6 \mathrm{ml}$ of chloroform and $4 \mathrm{ml}$ of distilled water was added. After stirring it was allowed to stand for $15 \mathrm{~min}$ in separating funnel till the two layers get separated. Lower layer containing pigments was rejected and upper layer was collected. The final volume of upper layer was made $10 \mathrm{ml}$ by adding distilled water and used to estimate proline content by using ninhydrin reagent (Bates et al., 1973). $5 \mathrm{ml}$ of sample solution was taken and $2.5 \mathrm{ml}$ of acid ninhydrin $(125 \mathrm{mg}$ of ninhydrin mixed in $3 \mathrm{ml}$ of acetic acid and $2 \mathrm{ml}$ of orthophosphoric acid, and then kept in oven at $70^{\circ} \mathrm{C}$ till a clear solution was formed) reagent was added to it. The mixture was boiled for $45 \mathrm{~min}$. The tubes were immediately cooled by keeping in ice bucket. Then $5 \mathrm{ml}$ of benzene was added and vortexed in cyclomixture. Two layers were formed and absorbance of upper layer was recorded at $515 \mathrm{~nm}$ by using benzene as blank. Proline was used as standard to make standard curve.
Characterization of protein in seeds: The seed samples taken from treated and control plants were powdered in a hand grinder. The four fractions were separated by using Pant and Tulsiani method (1969). Albumins: The powdered seed sample was extracted in $5 \mathrm{ml}$ of distilled water and centrifuged at 10,000 rpm for $30 \mathrm{~min}$. The supernatant of this extract contained albumins.

Globulins: The residue obtained was washed, dried and powdered and treated with $5 \mathrm{ml}$ of $0.5 \mathrm{~N}$ sodium chloride, then centrifuged at $10,000 \mathrm{rpm}$ for $30 \mathrm{~min}$. The supernatant obtained contained globulins. Prolamins: The residue obtained after extraction with $0.5 \mathrm{~N} \mathrm{NaCl}$ was washed, dried, powdered and then treated with $5 \mathrm{ml}$ of isopropanol $(50 \%)$ and centrifuged at $10,000 \mathrm{rpm}$ for $30 \mathrm{~min}$. The supernatant obtained upon this extraction contained alcohol soluble proteins called prolamins.

Glutelins: Extracted with $5 \mathrm{ml}$ of $\mathrm{KOH}(1 \mathrm{~N})$ solution followed by centrifugation at $10,000 \mathrm{rpm}$ for 30 minutes. This supernatant contained glutelins.

To the fractions extracted from (1-4), $1 \mathrm{ml}$ of $20 \%$ trichloroacetic acid (TCA) was added and kept for 24 hours. This extract was centrifuged for $20 \mathrm{~min}$ at 5000 rpm and the precipitates so obtained were dissolved in $0.1 \mathrm{~N} \mathrm{NaOH}$. Estimation of proteins was done by Lowry et al. (1951) method. SDS-PAGE electrophoresis of proteins was carried out by the method by Laemalli (1970).

No. of filled pods: The total number of filled pods of six randomly selected plants was counted at harvest.

\section{RESULTS}

Total chlorophyll content: It was observed that salt stress $(20$ and $30 \mathrm{mM} \mathrm{NaCl})$ decreased the total chlorophyll content in chickpea genotypes at vegetative (65DAS), flower initiation (90DAS) and pod initiation (110DAS) stages (Fig. 1). the decrease was more pronounced with $30 \mathrm{mM} \mathrm{NaCl}$ concentration. The chickpea genotypes showed a variation of total chlorophyll content even under normal conditions. The decrease in chlorophyll content was more pronounced at vegetative stage in ICC15868 and GL26054 (desi) and L552 (kabuli) chickpea genotypes both at 20 and $30 \mathrm{mM} \mathrm{NaCl}$. Similar trend was observed at flower and pod initiation stages. Maximum chlorophyll content was recorded at pod initiation stage. ICC8950 and ICCV10 (desi) and BG1053 and L550 (kabuli) showed minimum chlorophyll degradation both at 20 and $30 \mathrm{mM} \mathrm{NaCl}$ salt stress respectively at pod initiation stage. Maximum degradation of chlorophyll content due to salt stress was recorded with GL26054 and ICC15868. It was observed that salt stress $(30 \mathrm{mM} \mathrm{NaCl})$ caused more than $50 \%$ reduction in chlorophyll content in ICC15868 and GL26054 at pod initiation stage whereas corresponding decrease in ICC8950, ICCV10, BG1053 and L550 was found to be minimum and 


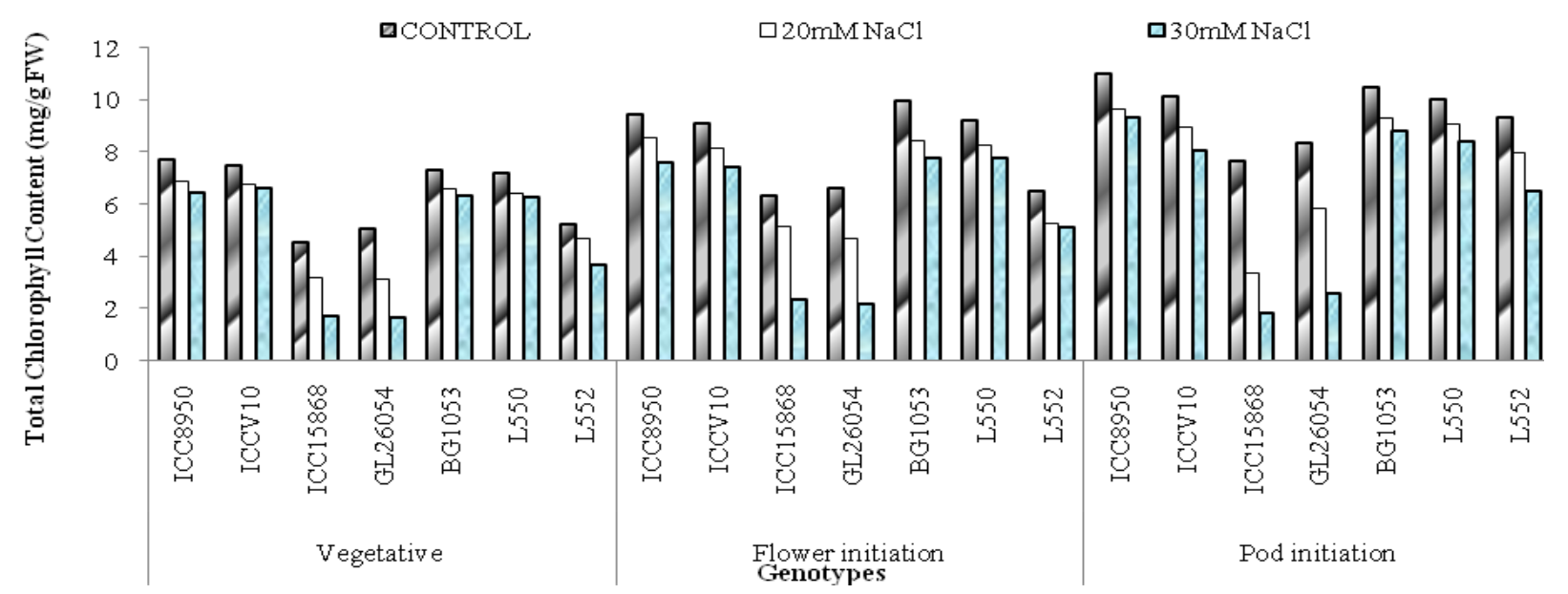

Fig. 1. Variation in total chlorophyll content $\left(\mathrm{mg} \mathrm{g}^{-1} \mathrm{FW}\right)$ of chickpea genotypes as influenced by salt stress at various growth.

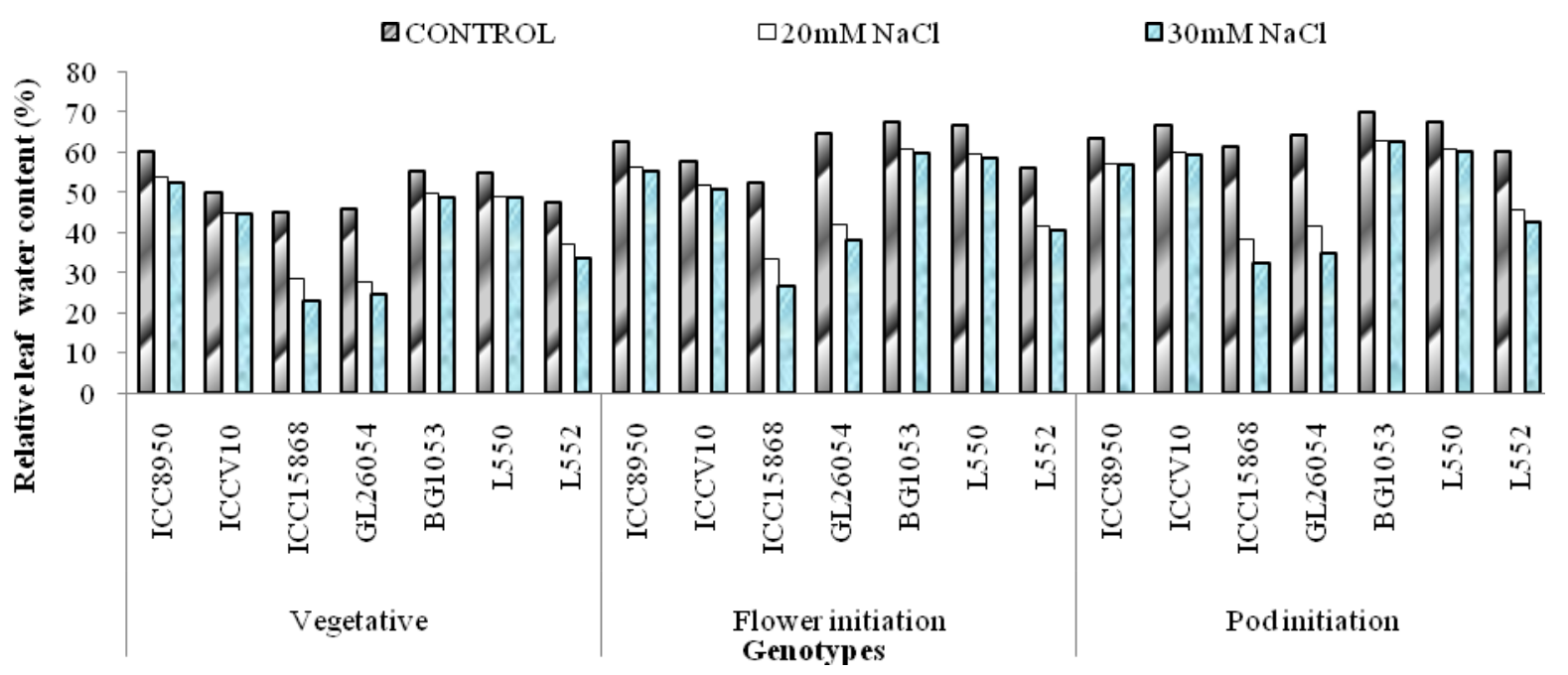

Fig. 2. Variations in relative leaf water content (\%) of chickpea genotypes as influenced by salt stress at various growths stages.

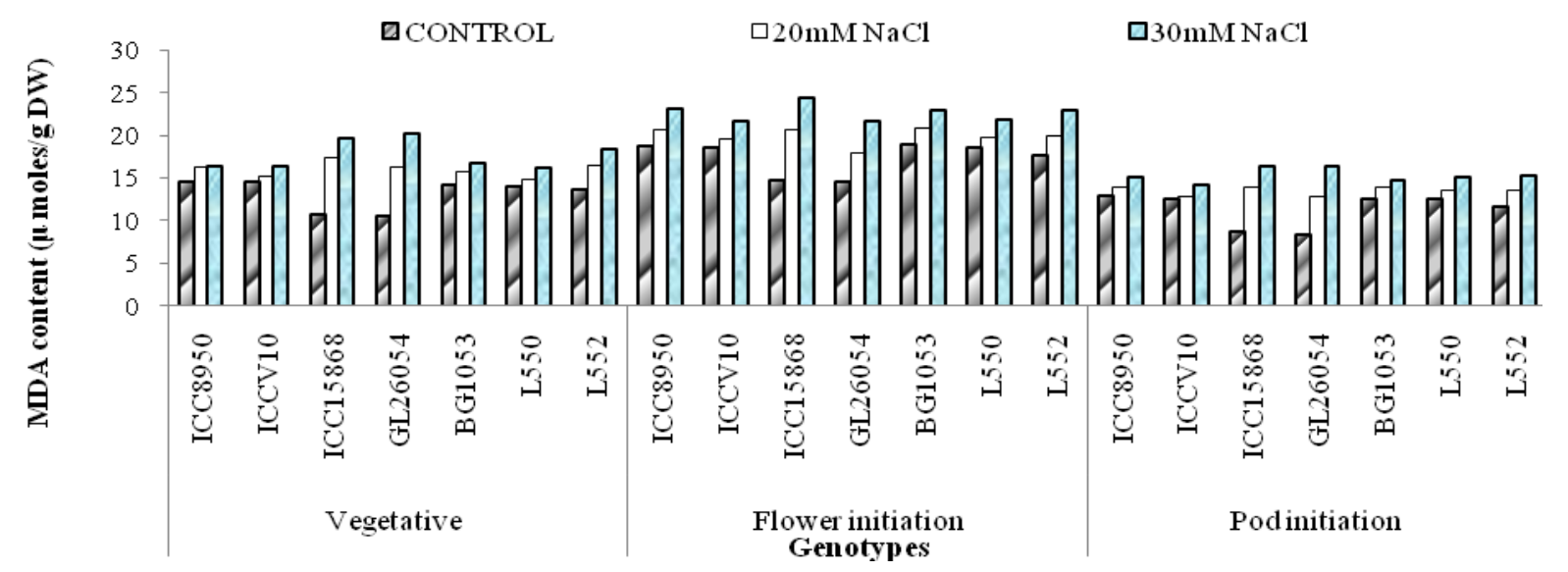

Fig. 3. Variations in lipid peroxidation ( $\mu$ moles $g^{-1} D W$ ) of chickpea genotypes as influenced by salt stress at various growth stages.

L552 showed moderate decrease.

Relative leaf water content: Relative leaf water content of chickpea genotypes was significantly reduced with increasing salinity and the magnitude of the reduction varied among genotypes at all the three stages of growth as shown in Fig 2. Salinity-imposed osmotic stress leads to cell turgor loss and cell volume change. The minimum percentage reduction in relative leaf water content at vegetative stage was recorded in ICC8950 and ICCV10 and the maximum percentage reduction was recorded in GL26054 and ICC15868 desi genotypes both at 20 and $30 \mathrm{mM} \mathrm{NaCl}$ 


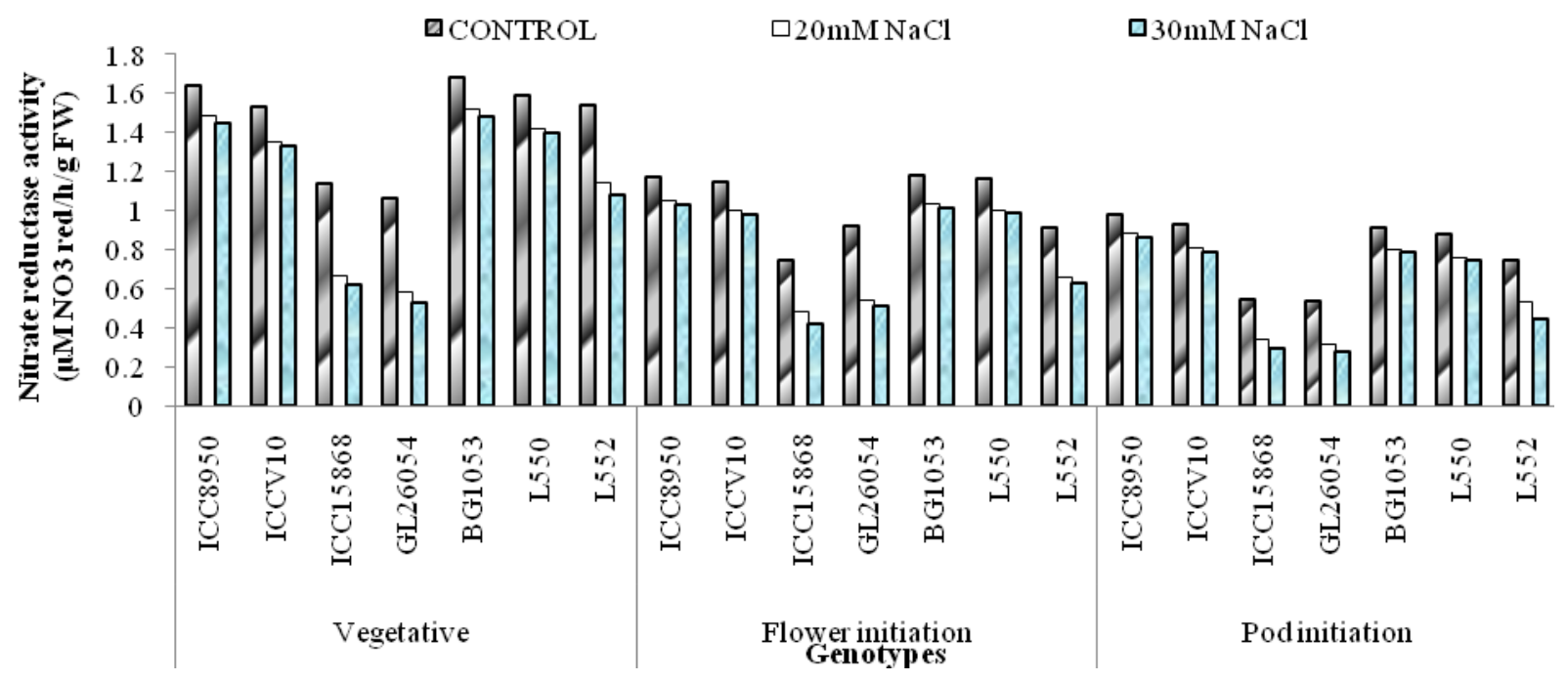

Fig. 4 . Variations in nitrate reductase activity $\left(\mu \mathrm{MNO} \mathrm{N}_{3}\right.$ red $\left.\mathrm{hr}^{-1} \mathrm{~g}^{-1} \mathrm{FW}\right)$ of chickpea genotypes as influenced by salt stress.

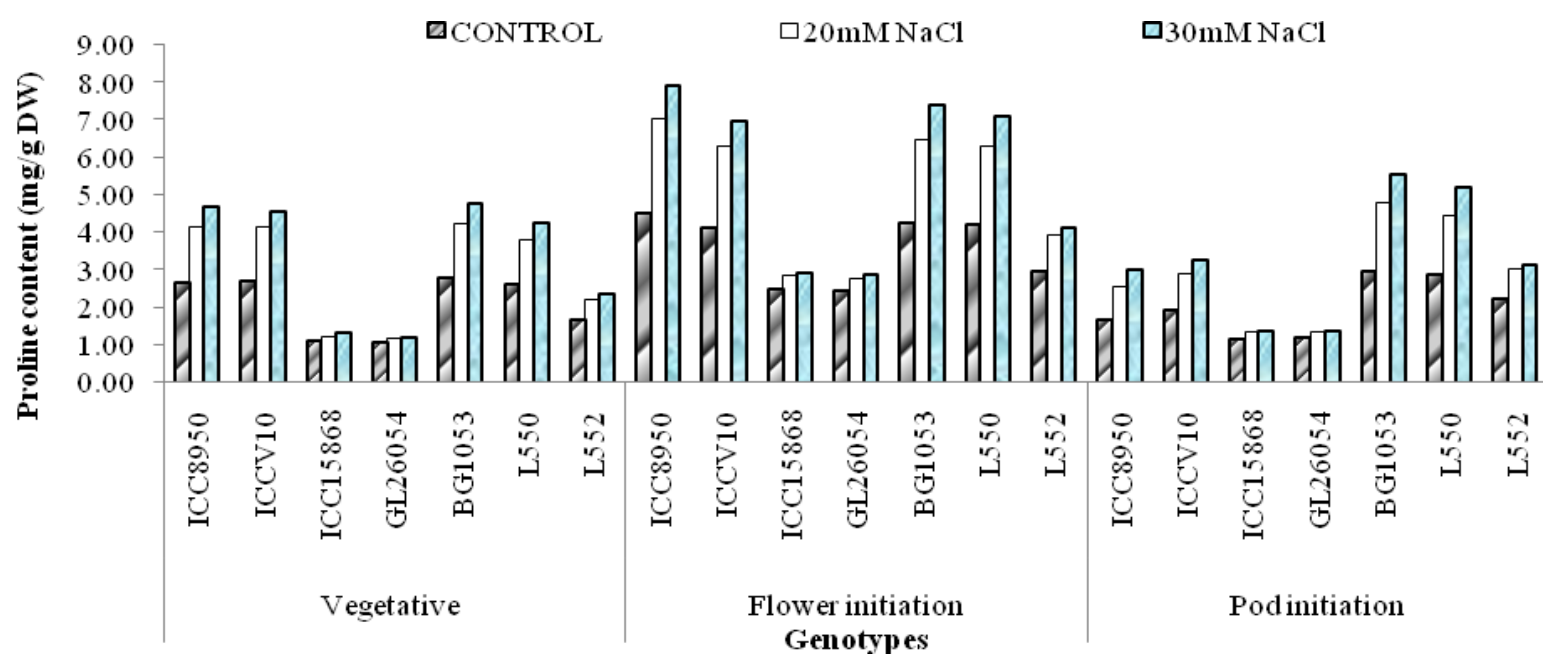

Fig. 5. Variations in proline content ( $\mathrm{g} \mathrm{g}^{-1} \mathrm{DW}$ ) of chickpea genotypes as influenced by salt stress at various growth stages.

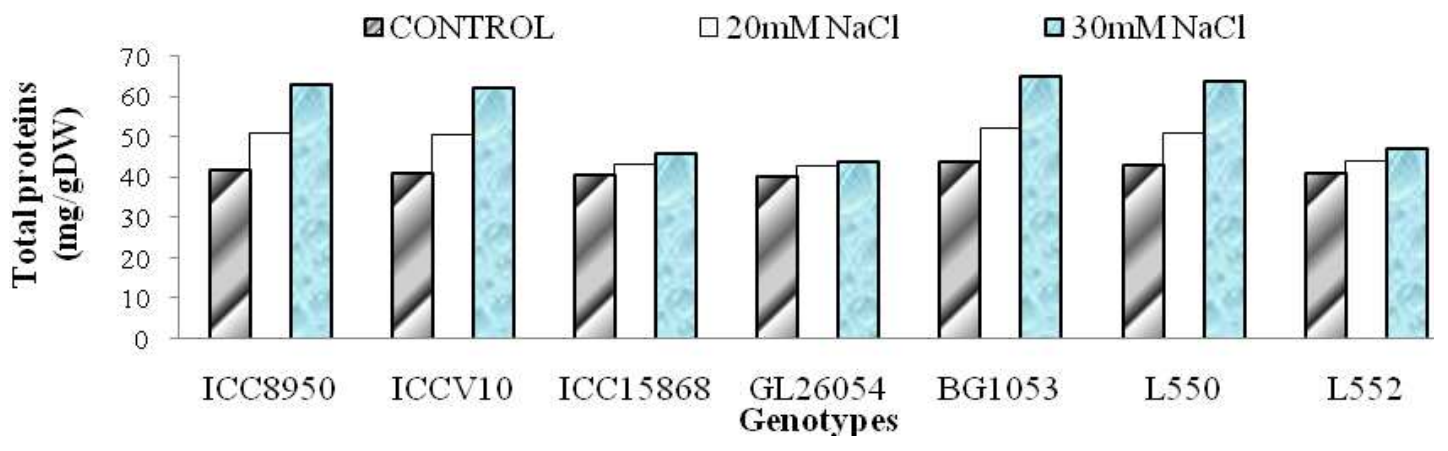

Fig. 6. Variations in total protein $\left(\mathrm{mg}^{-1} \mathrm{DW}\right)$ in seeds of chickpea genotypes as influenced by salt stress at maturity.

respectively. Among the kabuli genotypes, the minimum percentage reduction was recorded with BG1053 and L550 while the genotype L552 showed the moderate reduction under salt stress both at 20 and 30 $\mathrm{mM} \mathrm{NaCl}$ respectively. Similar trend was observed in all the seven genotypes at flower initiation and pod initiation stages. It was observed that RLWC in
ICC8950, ICCV10, BG1053 and L550 was decreased by 11 to $13 \%$ and 12 to $14 \%$ with 20 and $30 \mathrm{mM}$ salt application respectively at flower initiation stage. The reduction in RLWC was found to be higher in ICC15868 and GL26054 i.e. 38 to $46 \%$ in desi genotypes as compared to ICC8950 and ICCV10 where reduction was 11 to $14 \%$ at pod initiation stage. 


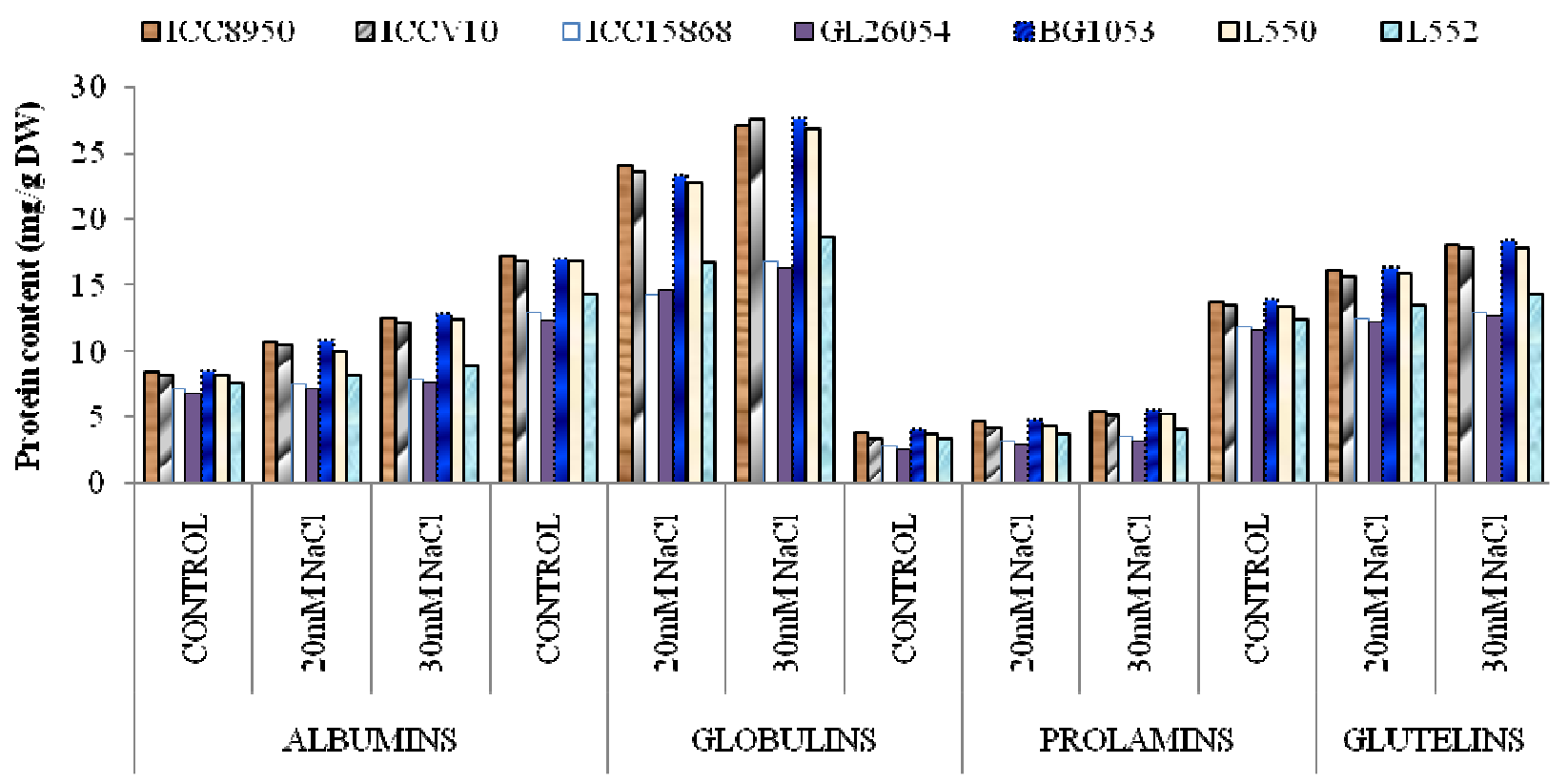

Protein fraction

Fig. 7. Variation in different protein fractions (albumins, globulins, prolamins and glutelins) $\left(m g g^{-1} D W\right)$ in seeds of chickpea genotypes as influenced by salt stress at various growth stages.

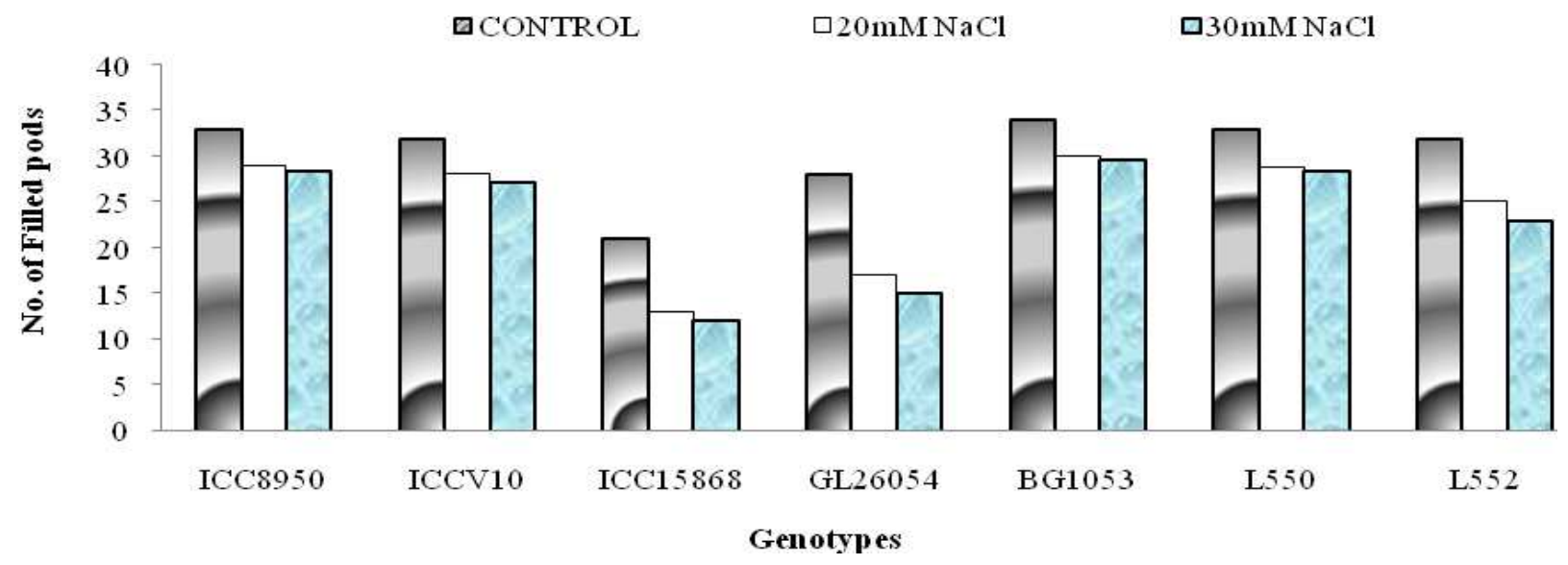

Fig. 8. Variations in number of filled pods per plant of chickpea genotypes as influenced by salt stress.

Lipid peroxidation: Lipid peroxidation was determined by evaluating malondialdehyde (MDA) contents of the leaf tissues. In our study, MDA concentration increased at all levels of $\mathrm{NaCl}$ treatments when compared to control indicating that salinity induces oxidative stress (Fig 3). The maximum increase in MDA level was observed at $30 \mathrm{mM} \mathrm{NaCl}$ in all the genotypes but less increment was noticed in ICC8950 and ICCV10 among the desi, while among the kabuli genotypes BG1053 and L550 showed the similar results at all stages of growth and under the salt stress also. The maximum increment in MDA level was noted in genotypes ICC15868 and GL26054 among the desi, and L550 among the kabuli genotypes under both 20 and $30 \mathrm{mM} \mathrm{NaCl}$ application.

Nitrate reductase: The enzyme activity was measured at the three growth stages viz. vegetative, flower inititation and pod initiation stage. The maximum enzyme activity was observed at 65 DAS (Fig 4). BG1053 and L550 in kabuli genotypes and ICC8950 and ICCV10 in desi genotypes had the highest enzyme activity was while GL26054 and ICC15868 marked the lowest activity in control. Salt stress decreased the activity in all the cultivars at all the stages but the decrease was less in BG1053, L550, ICC8950 and ICCV10 whereas the maximum reduction was observed in GL26054 and ICC15868 as compared to other genotypes. Similar trend was observed for all the genotypes at flower and pod initiation stages.

Proline content: The content of proline increased upto flower initiation stage thereafter decreased (Fig. $5)$. The proline content was found to be maximum in BG1053 (2.79 $\left.\mathrm{mgg}^{-1} \mathrm{DW}\right)$, L550 (2.60 mgg-1 DW), ICC8950 (2.67 $\left.\mathrm{mgg}^{-1} \mathrm{DW}\right)$ and ICCV10 (2.70 $\mathrm{mgg}^{-}$ $\left.{ }^{1} \mathrm{DW}\right)$ while the minimum proline content was recorded with GL26054 (1.04 $\left.\mathrm{mgg}^{-1} \mathrm{DW}\right)$ and 


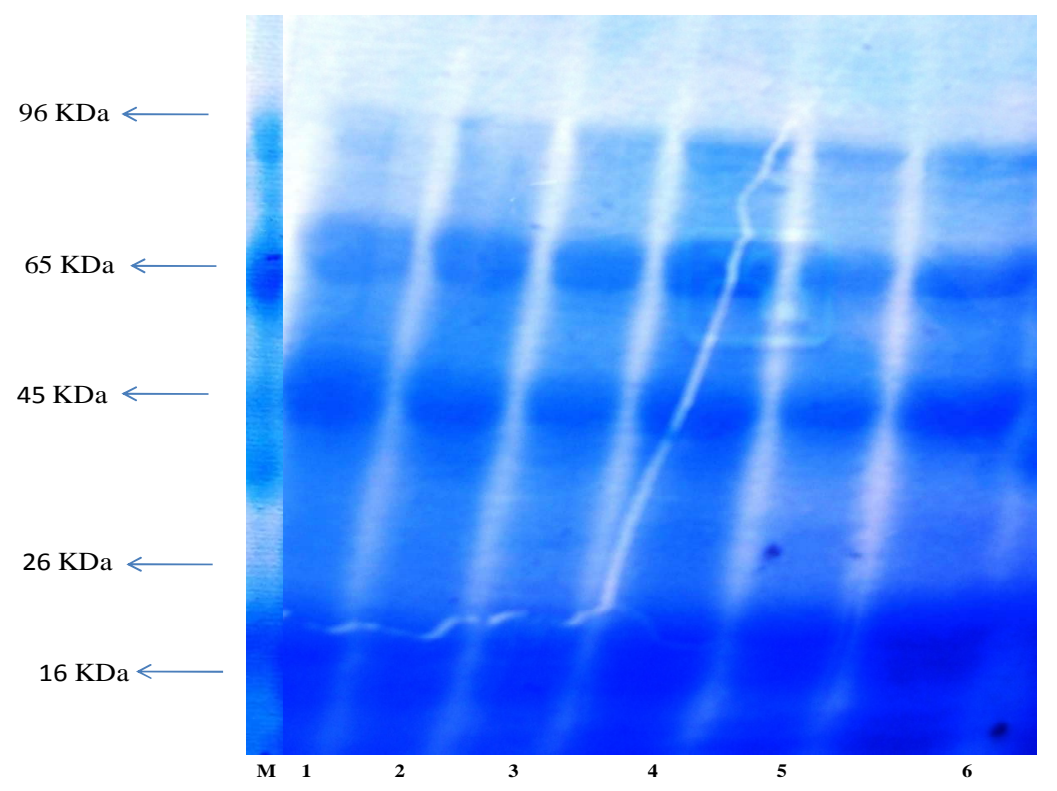

Fig. 9. Comparative SDS-PAGE protein profiles of total proteins in tolerant chickpea genotypes (ICC 8950 and ICCV 10) under control and salt stress. Lanes : M-Page Ruler TM (Prestained protein ladder); Lane : I- ICC 8950 (Control), Lane : 2-ICC 8950 (30mM), Lane:4- ICCV 10 (Control) Lane: 5-ICCV 10 (20mM); Lane: 6-ICCV 10 (30mM).

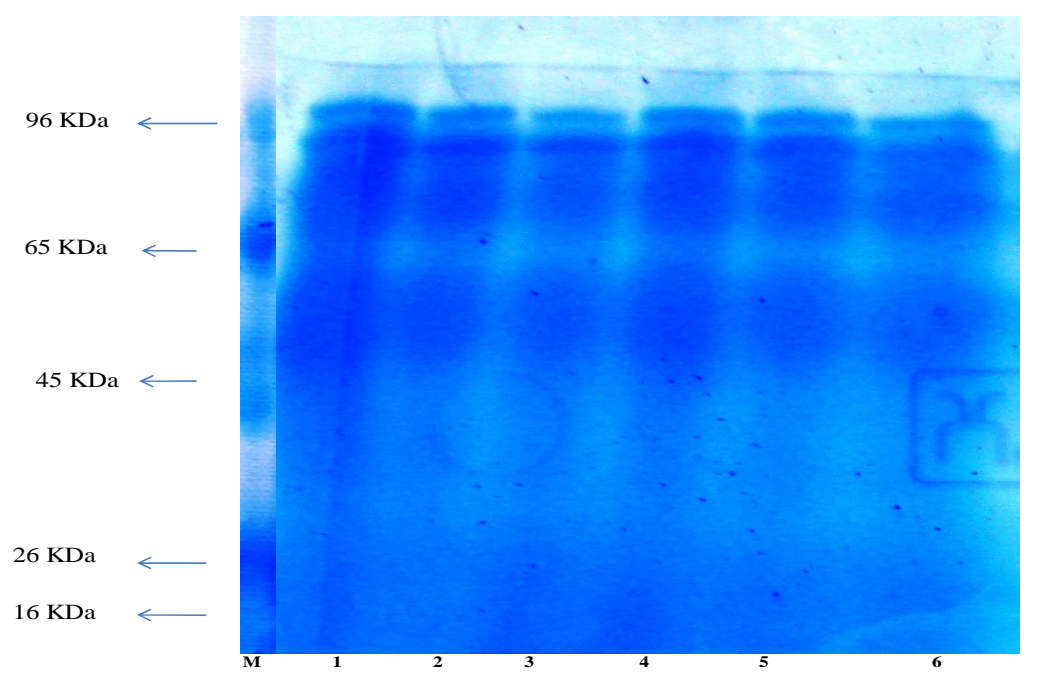

Fig. 10. Comparative SDS-PAGE protein profiles of total proteins in sensitive chickpea genotypes (ICC15868 and GL26054) under control and salt stress. Lanes: M- Page Ruler TM (Prestained Protein Ladder); Lane 1:ICC15868 (Control), Lane 2: ICC15868 (20mM), Lane 3: ICC15868 (30mM), Lane 4: GL26054 (Control), Lane 5: GL26054 (20mM), Lane 6: GL26054 $(30 \mathrm{mM})$.

ICC15868 (1.10 $\left.\mathrm{mgg}^{-1} \mathrm{DW}\right)$ in control at vegetative stage. Salt stress at 20 and $30 \mathrm{mM} \mathrm{NaCl}$, increased the proline content in $\mathrm{BG} 1053\left(4.23,4.78 \mathrm{mgg}^{-1} \mathrm{DW}\right)$, L550 (3.80, $\left.4.25 \mathrm{mgg}^{-1} \mathrm{DW}\right)$, ICC8950 (4.14, $4.67 \mathrm{mgg}$ $\left.{ }^{-1} \mathrm{DW}\right)$, ICCV10 (4.13, $\left.4.56 \mathrm{mgg}^{-1} \mathrm{DW}\right)$ respectively. The minimum increase in proline content was observed with GL26054 $\left(1.15,1.20 \mathrm{mgg}^{-1} \mathrm{DW}\right)$ and ICC15868 (1.22, $\left.1.31 \mathrm{mgg}^{-1} \mathrm{DW}\right)$. During flower initiation and pod initiation stages, the maximum proline accumulation was recorded with BG1053, L550, ICC8950 and ICCV10 under non saline conditions. Under the salt stress of $20 \mathrm{mM}$ and 30 $\mathrm{mM} \mathrm{NaCl}$ the maximum value of proline accumulation was recorded with BG1053 and L550 from the kabuli chickpea genotypes, from the desi genotypes ICC8950 and ICCV10 and the minimum accumulation was noticed in GL26054 and ICC15868 respectively.

Protein characterization: The data on effect of salt stress on total protein and different protein fractions (albumins, globulins, prolamins and glutelins) in seeds of chickpea genotypes are shown in Figs. 6 and 7. The perusal of data reveals that salt stress increased the total protein content as well as different protein fractions in all chickpea genotypes. Maximum increase in protein content was observed in ICC8950, ICCV10, BG1053 and L550 with $30 \mathrm{mM} \mathrm{NaCl}$. Protein content in ICC15868, GL26054 and L550 was increased to a very small amount with salt stress. Globulins content 


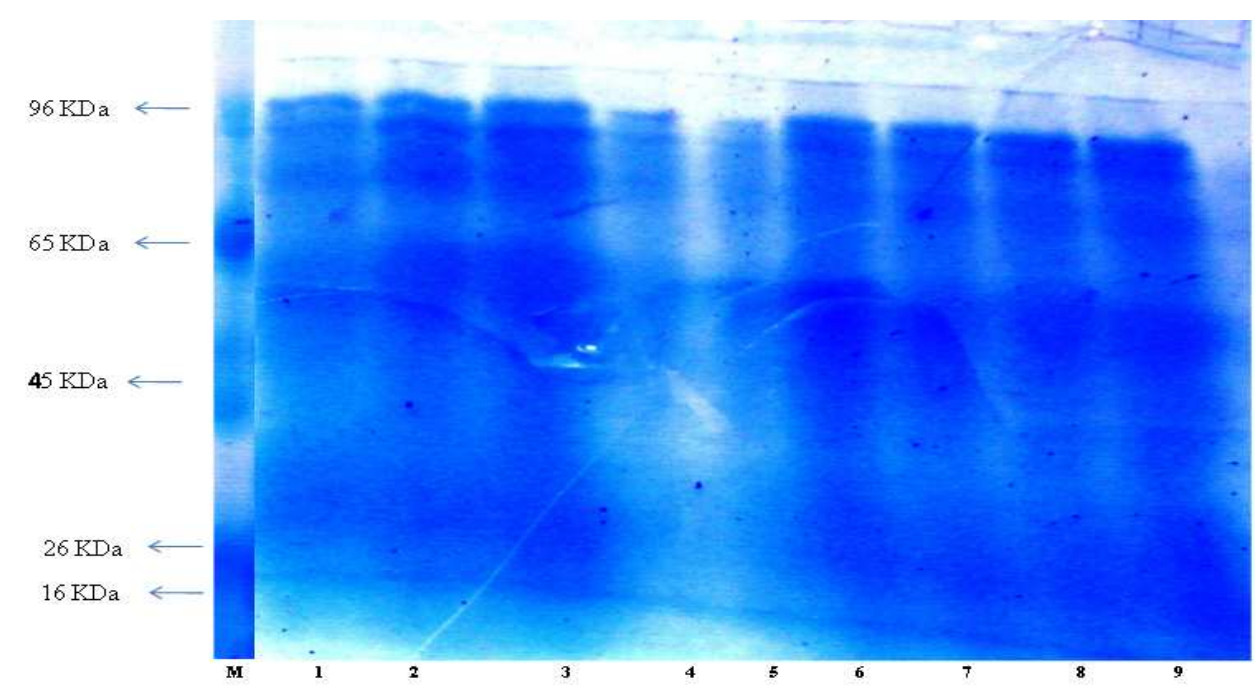

Fig. 11. Comparative SDS-PAGE protein profiles of total proteins in chickpea genotypes (BG1053, L552 and L550) under control and salt stress. Lanes : M- Page Ruler TM (Prestained Protein Ladder); Lane1: BG1053 (Control), Lane 2: BG1053 (20mM) Lane 3: BG1053 (30mM), Lane 4: L552 (Control), Lane 5: L552 (20mM), Lane 6: L552: (30mM) Lane 7: L550 (Control), Lane 8: L550 (20mM), Lane 9: (30mM).

was found to be maximum and prolamin content was found to be minimum in chickpea genotypes.

Number of filled pods per plant: Number of filled pods is one of the important yield contributing attribute and the data pertaining to its significant percentage reduction under salinity is presented in Fig. 8. Higher salinity level $(30 \mathrm{mM} \mathrm{NaCl})$ caused $14 \%$ decrease in number of filled pods of in BG1053, L550, ICC8950 and ICCV10 and about 46\% decline in GL26054, ICC 15868 .

Protein profiling (SDS-PAGE): Fig. 9 represents the comparative SDS-PAGE protein profiles of total proteins in tolerant chickpea genotypes (ICC8950 and ICCV10) under control and stress. Bands of molecular weight greater than $96 \mathrm{KDa}$ are present in ICCV10 and absent in ICC8950 under control and salt stress. Bands of molecular weight $16 \mathrm{KDa}$ are slightly more dense under salt stress than control. No significant variation in protein bands was observed under stress in genotypes ICC 8950 and ICCV10 at both the stress concentrations. Fig. 10 represents the comparative SDS-PAGE protein profiles of sensitive genotypes i.e. ICC15868 and GL26054 under control and salt stress. Results were found to be non significant in both the genotypes under salt stress. Fig 11 revealed the SDS-PAGE protein profiles of total proteins in kabuli chickpea genotypes viz. BG1053, L552 and L550 under control and salt stress. BG1053 and L552 showed upregulation of proteins under salt stress as compared to their control. L550 showed a non significant result i.e no variation among the different bands of proteins was observed.

\section{DISCUSSION}

Chickpea genotypes subjected to different concentrations of salt stress showed a decrease in photosynthetic pigments. Salinity stress had negative impact on chlorophyll content. It was observed that BG1053 and L550 (kabuli) and ICC8950 and ICCV10 (desi) showed the minimum decrease in chlorophyll content under salt stress whereas ICC15868 and GL26054 showed maximum decrease in chlorophyll content under both applications of salt stress. The minimum degradation of chlorophyll content in chickpea genotypes under salt stress indicates their better photosynthetic ability. The decline in photosynthesis due to salinity stress could be due to lower stomata conductance, depression in carbon uptake and metabolism, inhibition of photochemical capacity, or a combination of all these factors (Mundree et al. 2002). Photosynthetic pigments decreased in chickpea grown under salt stress (Beltagi 2008) and photosynthesis was reduced to $60 \%$ (Murumkar and Chavan 1993). The inhibitory effects of salt stress on chlorophyll pigments could be due to suppression of specific enzymes responsible for the synthesis of the green pigments, or due to increased chlorophyllase activity in wheat, Catharanthus roseus and mustard respectably (Kiani et al. 2005; Mishra et al. 2006).

Water uptake by plants hence, attains importance under saline conditions. To overcome the external stress plant cells tend to re-adjust their osmotic potential to prevent water losses that can be achieved either by uptake of inorganic ions or by de novo synthesis of compatible solutes. In the present investigation genotypes having minimum chlorophyll degradation were found to have minimum reduction in RLWC. This indicates that these cultivars had the capacity to synthesize photo-assimilates under stressed conditions that could be directed for pod and seed setting under stressed conditions. Kabir et al. (2004) also reported that salinity decreased RLWC and water retention capacity, while increased water saturation deficit and water uptake capacity in mung bean. 
The level of lipid peroxidation was measured by estimating malondialdehyde content (MDA). MDA has been widely used as a selection criterion to assess salt injury in various plants (Katsuhara et al., 2005; Jaleel et al., 2007). Results showed that the maximum increase in MDA level was observed in ICC15868 and GL26054 genotypes having maximum chlorophyll degradation and reduction in RLWC under the salt stress indicating that they are more prone to oxidative stress, which is responsible for the generation of ROS that are deleterious to plants and cause damage to biomolecules such as lipids, proteins and nucleic acids (Apel and Hirt, 2004; Tuteja et al., 2009). Salt stress negatively affect the lipid peroxidation and has been reported in many plants, Brassica juncea (Ahmad et al., 2012), Vicia faba (Azooz et al., 2011) and Solanum tuberosum (Queiros et al., 2011).

Nitrate reductase being an important enzyme of nitrate assimilation and plays an important role in amino acid biosynthesis and protein synthesis. It was observed that salinity decreased the NR activity in ICC15868 and GL26054 genotypes. Decline in nitrate reductase activity under conditions of salinity may be due to enhanced degradation of nitrogen, the inhibition of nitrate reductase activity due to salt ions, or a reduced rate of enzyme synthesis due to the salinity.

Results showed increased accumulation of proline under salt stress in chickpea genotypes. The maximum proline was accumulation was observed in ICC8950, ICCV10, BG1053 and L550. Proline is a compatible osmolyte, and perform multiple functions in stress adaptation, recovery and signaling, stabilization of proteins and protein complexes in the chloroplast and cytosol and protection of the photosynthetic apparatus in plants (Szabados, and Savoure, 2009). Ashraf and Foolad (2007) suggested that the application of proline successfully improved stress tolerance in plants. Salinity decreased the number of filled pods per plant, however the reduction in number of filled pods was associated with an increase in pod abortion in salt sensitive chickpea genotypes. However, pollen viability, in vitro germination of pollen, or pollen tube growth were not affected by salinity in salt tolerant and sensitive chickpea genotypes under $40 \mathrm{mM} \mathrm{NaCl}$ (Turner et al., 2013).

The increase in protein content may be due to the fact that salinity enhances protein synthesis (Langdale et al., 1973) and promotes conversion of nitrogen into protein (Helal et al., 1975). Significant increase in seed protein content under saline conditions has also been reported by Ashraf (1989) in mashbean cultivars. It can be inferred that salinity activates the metabolism of plants and hence the accumulation of more immediate metabolites, by the cells. A higher content of soluble proteins has been observed in salt-tolerant than in salt-sensitive cultivars of wheat and rice (Maleki et al., 2014; Hakim et al., 2014). Protein accumulation is important for cell survival under salt stress as it causes membrane stabilizations. In our study, salt-tolerant genotypes had the highest proteins than salt-sensitive genotypes. In response to salt stress, plants make new proteins that help them to grow and develop under saline conditions. Salt-tolerant genotypes producing higher protein concentrations is due to higher efficiency of osmotic regulation mechanism in these plants which in turn causes decreasing sodium toxicity in cytoplasm compared to susceptible ones and the result is to prevent protein reduction under salt stress (Flowers and Yeo, 1995).

\section{Conclusion}

Seven chickpea genotypes both desi (ICC8950, ICCV10, ICC15868, GL26054) and kabuli (BG1053, L550, L552) were evaluated for salinity tolerance on the basis of physiological and biochemical parameters. Salinity inhibited photosynthetic efficiency by chlorophyll degradation and nitrogen assimilation in different genotypes of chickpea. On the basis of physiological and biochemical parameters genotypes ICC8950 and ICCV10 from the desi and BG1053 and L550 from kabuli were identified as the tolerant while ICC15868, GL26054 as the sensitive ones and L552 as the moderately tolerant genotype. These tolerant genotypes had minimum reduction in chlorophyll content, relative leaf water content and MDA level accompanied by higher accumulation of proline and total proteins as compared to susceptible cultivars and the cumulative affect of these changes lead to amelioration of salinity stress tolerance in them.

\section{REFERENCES}

Ahmad, P., Hakeem, K.R., Kumar, A., Ashraf, M. and Akram, N.A. (2012). Salt- induced changes in photosynthetic activity and oxidative defense system of three cultivars of mustard (Brassica juncea L.) African Journal of Biotechnology, 11: 2694-2703.

Anonymous. (2009). Anti-waterlogging project, Department of Irrigation and Drainage, Punjab Government, India.

Apel, K. and Hirt, H. (2004). Reactive oxygen species: metabolism, oxidative stress, and signal transduction. Annual Review of Plant Biology, 55: 373-399.

Ashraf, M. (1989). The effect of $\mathrm{NaCl}$ on water relations, chlorophyll and protein and proline contents of two cultivars of blackgram. Plant and Soil, 119: 205-10.

Ashraf, M. and Foolad, M.R. (2007). Roles of glycine betaine and proline in improving plant abiotic stress resistance. Environmental Experimental Botany, 59 (2): 206-16.

Azooz, M.M., Youssef, A.M. and Ahmad, P. (2011). Evaluation of salicylic acid (SA) application on growth, osmotic solutes and antioxidant enzyme activities on broad bean seedlings grown under diluted seawater. International Journal of Plant Physiology and Biochemistry, 3: 25364.

Barr, H.D. and Weatherley, P.E. (1962). A re-examination of the relative turgidity technique for estimating water deficit in leaves. Australian Journal of Biological Science, 15: 413-28.

Bates, L.S., Waldeen,. R.P. and Teare, I.D. (1973). Rapid 
determination of free proline in water stress studies. Plant Soil, 39: 205-07.

Beltagi, M.S. (2008). Exogenous ascorbic acid (vitamin C) induced anabolic changes for salt tolerance in chickpea (Cicer arietinum L.) plants. African Journal of Plant Science, 2: 118-123.

Flowers, T.J. and Yeo, A.R. (1995). Breeding for salinity resistance in crop plants: Where next? Australian Journal of Plant Physiology, 22:875-884.

Flowers, T.J., Gaur, P.M., Gowda, C.L.L., Krishnamurthy, L., Samineni, S., Siddique, K.H.M., Turner, N.C., Vadez, V., Varshney, R.K. and Colmer, T.D. (2010) Salt sensitivity in chickpea. Plant Cell Environment, 33: 490-509.

Hakim, M.A. Juraim, A.S., Hanafi, M.M., Ismail M.R., Selamat. A, Rafii, M.Y. and Latif, M.A (2014). Biochemical and anatomical changes and yield reduction in rice (Oryza sativa L.) under varied salinity regimes. BioMed Research International . 2014: 1-11 http://dx.doi.org/10.1155/2014/208584

Hameed, A., Saddiqa, A., Nadeem, S.A., Iqbal, N., Atta, B. M. and Shah, T.M. (2012). Genotypic variability and mutant identification in Cicer arietinum L. by seed storage protein profiling. Pakistan Journal of Botany, 44:1303-1310

Harris, N., Foster, J.M., Kumar, A., Davies, H.V., Gebhardt, C. and Wray, J.L. (2000). Two cDNAs representing alleles of the nitrate reductase gene of potato (Solanum tuberosum L. cv. Desiree): sequence analysis, genomic organization and expression. Journal of Experimental Botany, 51: 1017-1026

Heath, R.L. and Packer, L. (1968). Photoperoxidation in isolated chloroplast I Kinetics and stoichiometry of fatty acid peroxidation. Archives of Biochemistry and Biophysics, 125:189-198.

Helal, M., Koch, K. and Mengel, K. (1975). Effect of salinity and potassium on the uptake of nitrogen metabolism in young barley plants. Physiology Plant, 35: 310-13.

Hiscox, J.D. and Israeltam G.F. (1979). A method for extraction of chlorophyll from leaf tissues without maceration. Canadian Journal of Botany, 51: 1332-34.

$\mathrm{Hu}, \mathrm{Y}$. and Schmidhalter, U. (2002). Limitation of salt stress to plant growth. In: Hock B, Elstner CF (eds) Plant toxicology. Marcel Dekker Inc. New York pp: 91-224.

Jaleel, C.A., Gopi, R., Sankar, B., Manivannan, P., Kishore kumar, A., Sridharan, R. and Panneerselvam, R. (2007). Studies on germination, seedling vigour, lipid peroxidation and proline metabolism in Catharanthus roseus seedlings under salt stress. South African Journal of Botany, 73: 190-95.

Jaworski, E.G. (1971). Nitrate reductase assay in intact plant tissue. Biochem Biophys Res Commun, 43: 1274-79.

Kabir, M.E., Karim, M.A. and Azad, M.A.K. (2004). Effect of potassium on salinity tolerance of mungbean (Vigna radiata L. Wilczek). Journal of Biological Science, 4(2): 103-10.

Katsuhara, M., Otsuka, T. and Ezaki, B. (2005). Salt stress induced lipid peroxidation is reduced by glutathione S-transferase, but this reduction of lipid peroxides is not enough for a recovery of root growth in Arabidopsis. Plant Science, 169: 369-73.

Kiani, A.J.K., Edgar, E.B. and Joseph, M.J. (2005). Mechanistic analysis of wheat chlorophyllase. Archives of Biochemistry and Biophysics, 438:146-55.

Kumar, V., Shriram, V., Kavi Kishor, P.B., Jawali, N. and
Shitole, M.G. (2010). Enhanced proline accumulation and salt stress tolerance of transgenic indica rice by over -expressing P5CSF129A gene. Plant Biotechnology Reports, 4:37-48.

Langdale, G.W.N., Thomas, J.R. and Littleton, T.G. (1973). Nitrogen metabolism of star grass as affected by nitrogen and soil salinity. Agronomy Journal, 65: 468-70.

Laemmli, U.K. (1970). Cleavage of structural proteins during the assembly of the head of bacteriophage T4. Nature, 227: 680-85.

Lowry, O.H., Rosenbrough, N.J., Farr, A.L. and Randall, R.J. (1951). Protein measurement with Folin-phenol reagent. Journal of Biological Chemistry, 193: 265275.

Meloni, D.A., Olivia, M.A., Martinez, C.A. and Cambraia, J. (2003). Photosynthesis and activity of superoxide dismutase, peroxidase and glutathione reductase in cotton under salt stress. Environment Experimental Botany, 49: 69-76.

Maleki, M., Naghavi, M.R., Alizadeh, H., Poostini, K. and Abd Mishani, C. (2014). Comparison of protein changes in the leaves of two bread wheat cultivars with different sensitivity under salt stress. Annual Research and Review in Biology, 4: 1784-1797

Metwally, A., Safronova, B.A. and Dietz, K.J. (2005). Genotypic variation of the response to cadmium toxicity in Pisum sativum L. Journal of Experimenal Botany, 56: 167-178.

Mishra, S., Tyagi, A., Singh, I.V. and Sangwan, R.S. (2006). Changes in lipid profile during growth and senescence of Catharanthus roseus leaf. Brazilian Journal of Plant Physiology, 18: 447-454.

Mundree, S.G., Baker, B., Mowla, S., Peters, S., Marais, S., Willigen, C.V., Govender, K., Maredza, A., Muyanga, S., Farrant, J.M. and Thomson, J.A. (2002). Physiological and molecular insights into drought tolerance. African Journal of Biotechnology, 1: 28-38.

Munns, R. and Tester, M. (2008). Mechanism of salinity tolerance. Annual Reviews of Plant Biology, 59: 65181.

Murumkar, C.V., Chavan, P.D. (1986). Influence of salt stress on biochemical processes in chickpea. Cicer arietinum L. Plant and Soil, 96: 439-43.

Pant, R. and Tulsiani, D.R.P. (1969). Soluble amino acid composition and biological evaluation of proteins isolated from leguminous seeds. Journal of Agricultural Chemistry, 17: 361.

Pareek, A., Singla, S.L. and Grover, A. (1997). Salt responsive proteins/genes in crop plants. In: Jaiwal P. K., Singh R.P., Gulati A. (Eds) Strategies for improving salt tolerance in higher plants. Oxford and IBH Publication Co., New Delhi, pp 365-91.

Queiros, F., Rodrigues, J.A., Almeida, J.M., Almeida, D.P. and Fidalgo, F. (2011). Differential responses of the antioxidant defence system and ultrastructure in a salt-adapted potato cell line. Plant Physioilogy and Biochemistry, 49:1410-1419.

Rasool, S., Ahmad, A., Siddiqi, T.O. and Ahmad, P. (2013), Changes in growth, lipid peroxidation and some key antioxidant enzymes in chickpea genotypes under salt stress. Acta Physiologia Plantarum, 35: 1039-1050.

Rao, D.L.N., Giller, K.E., Yeo, A.R. and Flowers, T.J. (2002). The effect of salinity and sodicity upon nodulation and nitrogen fixation in chickpea (Cicer arietinum). Annals of Botany, 89:563-570. 
Selvakumar, G., Kim, K. , Hu, S. and Sa, T. (2014). Effect of salinity on plants and the role of arbuscular mycorrhizal fungi and plant growth-promoting rhizobacteria in alleviation of salt stress physiological mechanisms and adaptation strategies in plants under changing environment. pp 115-144

Shakya, S.K. and Singh, J.P. (2010). New drainage technologies for salt-affected waterlogged areas of southwest Punjab, India. Current Science, 99 (2): 204-212.

Szabados, L. and Savoure, A. (2009). Proline: a multifunctional amino acid. Trends Plant Science, 15: 89-97.

Turner, N.C., Colmer, T.D,. Quealy, J., Pushpavalli, R., Krishnamurthy, L., Kaur, J., Singh, G., Siddique, K.H.
M. and Vadez, V. (2013). Salinity tolerance and ion accumulation in chickpea (Cicer arietinum L.) subjected to salt stress. Plant Soil, 365:347-361.

Tuteja, N., Ahmad, P., Panda, B.B. and Tuteja, R. (2009). Genotoxic stress in plants: shedding light on DNA damage, repair and DNA repair helicases. Mutation Research, 681: 134-149.

Zaccardelli, M., Sonnante, G., Lupo, F., Piergiovanni, A.R., Leghetti, G., Sparvoli, F. and Lioi, L. (2013). Characterization of italian chickpea (Cicer arietinum L.) germplasm by multidisciplinary approach. Genetics Resources and Crop Evolution, 60:865-877. 